\title{
A framework for the development and appraisal of diet and eating behaviour outcome measures
}

\author{
Dianne Ward ${ }^{2}$, Maria Bryant ${ }^{*}$, Claudia Gorecki ${ }^{1}$, Amber Vaughn², Rachel Tabak ${ }^{3}$, June Stevens ${ }^{2}$, Jane Nixon ${ }^{1}$, \\ Susan Jebb ${ }^{4}$, Kath Roberts ${ }^{5}$, Judy Wright ${ }^{1}$, Julia Brown ${ }^{1}$ \\ From 2nd Clinical Trials Methodology Conference: Methodology Matters \\ Edinburgh, UK. 18-19 November 2013
}

\section{Background}

Multiple existing tools provide guidance for developing and evaluating patient reported outcome measures (e.g. Scientific Advisory Committee (SAC) of the Medical Outcomes Trust guidelines, FDA guidance for Patient Reported Outcomes). Guidance is absent, however, for diet and eating behaviour outcome measures that can be used to evaluate community-based interventions.

\section{Aim}

To develop a framework to guide the development and appraisal of behavioural outcome measures of diet and eating behaviours.

\section{Methods}

An appraisal framework, based on relevant items from existing tools (i.e. COSMIN, FDA, EMPRO, SAC) was developed. Initial testing was conducted as part of a systematic review, in which data were extracted from 100 papers describing parental feeding practices measures (HomeSTEAD). Next, the framework was expanded to include a scoring system for items related to conceptual framework, reliability, validity and responsiveness testing. The expanded framework was then used in a systematic review of 353 papers describing outcome measures used in childhood obesity treatment evaluations (CoOR).

\section{Results}

An appraisal framework guided the development of extraction forms for diet and eating behaviour outcome measures. A key part of the framework was a scoring system, which enables individual outcome measures to be scored (1-4) to appraise measurement development (description of concept, use of population); reliability

${ }^{1}$ University of Leeds, Leeds, UK

Full list of author information is available at the end of the article (internal consistency, test re-test, inter-rater); validity (factor analysis, criterion, convergent, construct); and responsiveness.

\section{Conclusions}

This work provides a framework to enable researchers to appraise existing outcome measures for use in behavioural intervention trials and can guide development of new diet and eating behaviours outcome measures.

\section{Authors' details}

'University of Leeds, Leeds, UK. 'University of North Carolina, Chapel Hill, NC, USA. ${ }^{3}$ University in St. Louis, St. Louis, MO, USA. ${ }^{4}$ MRC Human Nutrition Research, Cambridge, UK. ${ }^{5}$ National Obesity Observatory, Oxford, UK.

Published: 29 November 2013

doi:10.1186/1745-6215-14-S1-P71

Cite this article as: Ward et al:: A framework for the development and appraisal of diet and eating behaviour outcome measures. Trials 2013 14(Suppl 1):P71.

Submit your next manuscript to BioMed Central and take full advantage of:

- Convenient online submission

- Thorough peer review

- No space constraints or color figure charges

- Immediate publication on acceptance

- Inclusion in PubMed, CAS, Scopus and Google Scholar

- Research which is freely available for redistribution

\section{Ciomed Central}

(c) 2013 Ward et al; licensee BioMed Central Ltd. This is an Open Access article distributed under the terms of the Creative Commons Attribution License (http://creativecommons.org/licenses/by/2.0), which permits unrestricted use, distribution, and reproduction in any medium, provided the original work is properly cited. 